This item was submitted to Loughborough's Research Repository by the author.

Items in Figshare are protected by copyright, with all rights reserved, unless otherwise indicated.

\title{
Experimental study of DI diesel engine performance using three different biodiesel fuels
}

PLEASE CITE THE PUBLISHED VERSION

http://www.sae.org/congress/2006/

PUBLISHER

(C) SAE International

VERSION

VoR (Version of Record)

LICENCE

CC BY-NC-ND 4.0

\section{REPOSITORY RECORD}

Patterson, Jill, M.G. Hassan, Andrew Clarke, Gilbert Shama, Mohamed G. Hassan-Sayed, Klaus Hellgardt, and Rui Chen. 2011. "Experimental Study of DI Diesel Engine Performance Using Three Different Biodiesel Fuels". figshare. https://hdl.handle.net/2134/8410. 
This item was submitted to Loughborough's Institutional Repository (https://dspace.lboro.ac.uk/) by the author and is made available under the following Creative Commons Licence conditions.

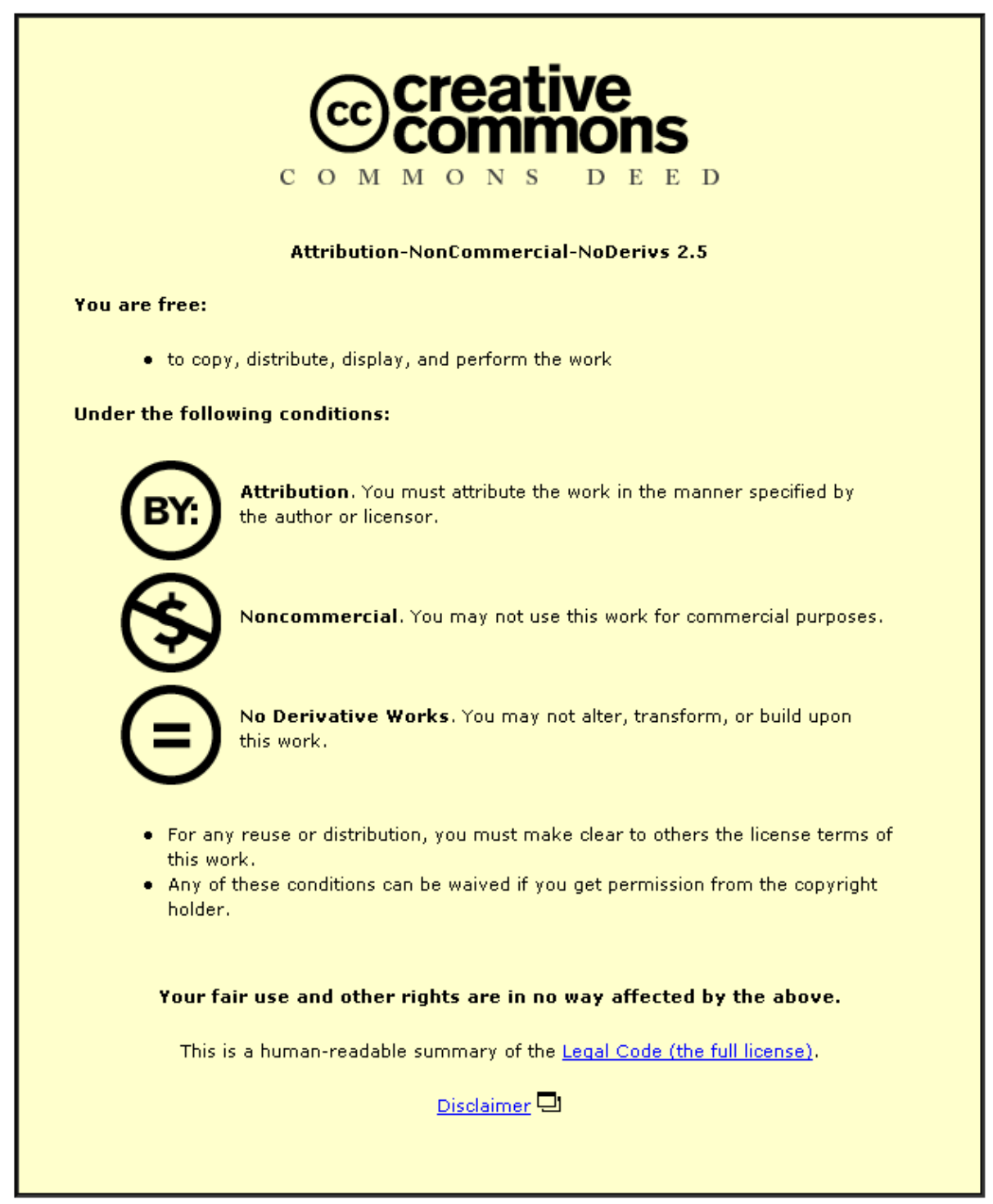

For the full text of this licence, please go to: http://creativecommons.org/licenses/by-nc-nd/2.5/ 


\section{Experimental Study of DI Diesel Engine Performance Using Three Different Biodiesel Fuels}

J. Patterson, M. G. Hassan, A. Clarke, G .Shama, K. Hellgardt and R. Chen

Loughborough University

Reprinted from: Emission: New Diesel Engines and Components and $\mathrm{Cl}$ Engine Performance for Use with Alternative Fuels (SP-2014)

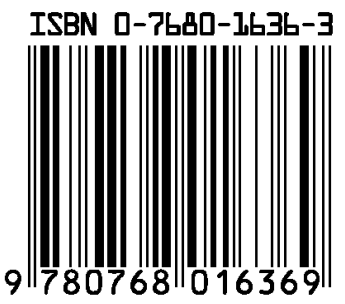


The Engineering Meetings Board has approved this paper for publication. It has successfully completed SAE's peer review process under the supervision of the session organizer. This process requires a minimum of three (3) reviews by industry experts.

All rights reserved. No part of this publication may be reproduced, stored in a retrieval system, or transmitted, in any form or by any means, electronic, mechanical, photocopying, recording, or otherwise, without the prior written permission of SAE.

For permission and licensing requests contact:

SAE Permissions
400 Commonwealth Drive
Warrendale, PA 15096-0001-USA
Email: permissions@ @ sae.org
Tel: $\quad 724-772-4028$
Fax: $\quad 724-776-3036$

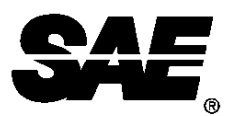

Global Mobility Database ${ }^{\circledR}$

All SAE papers, standards, and selected books are abstracted and indexed in the Global Mobility Database.

For multiple print copies contact:

\author{
SAE Customer Service \\ Tel: $\quad$ 877-606-7323 (inside USA and Canada) \\ Tel: $\quad$ 724-776-4970 (outside USA) \\ Fax: $\quad$ 724-776-0790 \\ Email: CustomerService@sae.org
}

\title{
ISSN 0148-7191
}

\section{Copyright $\odot 2006$ SAE International}

Positions and opinions advanced in this paper are those of the author(s) and not necessarily those of SAE. The author is solely responsible for the content of the paper. A process is available by which discussions will be printed with the paper if it is published in SAE Transactions.

Persons wishing to submit papers to be considered for presentation or publication by SAE should send the manuscript or a 300 word abstract to Secretary, Engineering Meetings Board, SAE.

\section{Printed in USA}




\title{
Experimental Study of DI Diesel Engine Performance Using Three Different Biodiesel Fuels
}

\author{
J. Patterson, M. G. Hassan, A. Clarke, G. Shama, K. Hellgardt and R. Chen \\ Loughborough University
}

Copyright (C) 2006 SAE International

\begin{abstract}
Methyl esters derived from vegetable oils by the process of transesterification (commonly referred as 'biodiesel'), can be used as an alternative fuel in compression ignition engines. In this study, three different vegetable oils (rape, soy and waste oil) were used to produce biodiesel fuels that were then tested in a four cylinder direct injection engine, typically used in small diesel genset applications. Engine performance and emissions were recorded at five load conditions and at two different speeds. This paper presents the results obtained for measurements of NOx and smoke opacity at the different speed and load conditions for the three biodiesels, and their blends ( 5 and $50 \% \mathrm{v} / \mathrm{v}$ ) with mineral diesel. A simple combustion analysis was also performed where ignition delay, position and magnitude of peak cylinder pressure and heat release rate were examined to asses how the variation of chemical structure and blend percentage affects engine performance.

Engine performance and emissions for all of the 5\% biodiesel blends were indistinguishable from mineral diesel. However, at higher blends, the rape fuel exhibited better emission and performance characteristics than either the soy or waste fuels. Furthermore; whilst emissions trends varied for each blend and fuel, emissions of smoke were significantly reduced at all speed and load conditions, and NOx was reduced by up to $50 \%$ at low loads. It will also be shown that while engine performance was not significantly deteriorated by biodiesel, there was evidence of increased ignition delay with higher blends, and a possible two stage ignition process where mineral diesel ignited earlier than the biodiesel.
\end{abstract}

\section{INTRODUCTION}

Concerns over the eventual depletion of the world's petroleum reserves have focused attention on the production of alternative renewable liquid fuels [1]. Closely allied to these concerns are issues relating to the environment and to the security of supply of transport fuels. Of the various alternatives suitable for compression ignition $(\mathrm{Cl})$ engines, biodiesel is emerging as a strong contender [2], and is becoming commercially available, albeit in limited quantities, in a number of countries.

Biodiesel most typically comprises a mixture of methyl esters derived from vegetable oils. Biodiesel may be used in existing diesel engines without necessitating engine modifications, and its use does not result in a shortening of engine life or the need for more frequent servicing [1]. Engine performance has been shown to be comparable to that for mineral diesel [3], as biodiesel has an energy density, cetane number (CN), viscosity (and other physical fuel properties) close to that of diesel [4]. Although the cost of production is typically higher than that of mineral diesel, subsidies and tax exemptions can be used to increase sales [5].

Biodiesel possesses certain environmental benefits. For instance, over its life cycle, it approaches carbon dioxide neutrality and therefore contributes less to global warming and environmental degradation [6]. Biodiesel is much less toxic than mineral diesel and so it can be used in environmentally sensitive areas such as national parks. Emission levels can also be reduced in comparison to mineral diesel [5].

The objective of the research presented here was to analyze the performance and to obtain emissions characteristics of a Cl four cylinder Direct Injection (DI) industrial engine whilst fuelled on three different types of biodiesel fuels in order to investigate how performance characteristics vary with difference source oils. The fuels that were tested here were a rapeseed oil derivative, as this is commonly used in Europe, and a soy oil derivative, as this is commonly used in USA. The third fuel was a waste cooking oil derivative, as this could conceivably form part of a waste oil recycling strategy. Emissions of NOx and visible smoke are reported upon in this study, as they are regarded as the main emissions of interest in $\mathrm{Cl}$ engines.

A second objective of this research was to asses to what extent the performance of a standard, unmodified $\mathrm{Cl}$ would change when fuelled with biodiesel. This is 
because blending mineral and biodiesel fuels is seen in Europe as the likeliest strategy for meeting EU-imposed targets for increased use of renewable energy sources (2003/30/EC) [5].

\section{BIODIESEL FUELS}

\section{PRODUCTION OF BIODIESEL}

Biodiesel was produced by the transesterification of vegetable oil triglycerides with methanol in the presence of sodium hydroxide catalyst. All three types of oil were converted using a temperature controlled glass batch vessel of volume 5 liters at $338 \mathrm{~K}$ and at atmospheric pressure with a fixed molar ratio of methanol to vegetable oils of $6: 1$, and agitation was maintained at $500 \mathrm{rpm}$ throughout the 30 minute duration of the reaction. Once the reaction was terminated, the contents of the reactor were centrifuged for 2 hours to remove the glycerol by-product and the ester phase was washed using acidified water to remove soaps and other impurities. A single batch of each fuel was produced, and then blended with mineral diesel as required. Each of the three biodiesel fuel batches was used within 12 hours of production.

Three blends of each of the biodiesel fuels were then tested. These were 5, 50 and $100(\% \mathrm{v} / \mathrm{v})$ blends of Soya (S), Rape (R) and Waste (W) biodiesel, (referred to as S5, S50, S100, R5, R50, R100 and W5, W50 and W100 respectively). Standard diesel fuel No 2 (ESSO Ultra Low Sulphur Diesel table A1) was used for the baseline tests, and was also used to create the biodiesel blends. Blends were obtained by adding the requisite amounts of both fuels in a vessel of 5 liters capacity and mixing the contents for 5 minutes using an agitator equipped with a marine impeller, operating at $50 \mathrm{rpm}$.

\section{MEASUREMENT OF FUEL PROPERTIES}

The physical and chemical properties of the different fuels have a direct effect on the engine performance through the injection, ignition and combustion processes. The properties that have a direct impact on engine performance are viscosity, calorific value, density, chemical composition, mixture properties and cetane number.

\section{$\underline{\text { Viscosity }}$}

A HAAKE rotational viscometer (ViscoTester model VT550) was used with a rotor MV2 head.

$\underline{\text { Lower Calorific value }}$

LCV was measured using a bomb calorimeter ('Autobomb', Gallenkamp Ltd.). Samples were placed in gelatine capsules burnt in pure oxygen. LCV is a reflection of the quality of stored energy with in the fuels, and over all the different oils biodiesel have similar LCV; that is less than mineral diesel by about $5 \%$ this leads to a reduction in power (see table 5).

\section{TEST FACILITY AND PROCEDURE}

The engine used in this study was a Lister-Petter inline four cylinder DI diesel engine, typically used in small diesel genset applications. Details of the engine specification are given in table 1 .

The engine was coupled to a Heenan-Dynamatic Mkll $220 \mathrm{~kW}$ eddy current dynamometer. Torque was measured by means of a strain gauge load cell connected to the lever arm, and speed by means of a magnetic pick-up that generated a voltage signal with the passing of each gear tooth of a 60 toothed wheel. Intake airflow was measured using a laminar viscous flow air meter with a type 5 Cussons manometer: inlet air depression was measured by a Druck general purpose pressure transducer coupled to a digital readout. Various temperatures around the engine were measured via ' $\mathrm{K}$ type' thermocouples for inlet air, cooling water before and after the cylinder head, exhaust gas and diesel fuel. Diesel fuel consumption was recorded using a volumetric fuel measurement system. The installation is shown schematically in figure 1.

\begin{tabular}{|l|l|}
\hline Engine Type & $\begin{array}{l}\text { Lister-Petter 4x90, DI, } \\
\text { 4stroke diesel }\end{array}$ \\
\hline Configuration & Vertical in-line 4 cylinder \\
\hline Cylinder Bore & $90 \mathrm{~mm}$ \\
\hline Cylinder Stroke & $90 \mathrm{~mm}$ \\
\hline Compression Ratio & $18.5: 1$ \\
\hline Displacement & 2.29 litres \\
\hline Rated Speed & 1800 rpm \\
\hline Rated Power & $37.5 \mathrm{~kW}$ at 2100 rpm \\
\hline Maximum Torque & $143 \mathrm{Nm}$ at 2000 rpm \\
\hline Cooling & Water \\
\hline Breathing & Naturally Aspirated \\
\hline Fuel Injection Equipment & Lucas Rotary Pump \\
\hline & specifications \\
\hline
\end{tabular}

High-speed data, comprising of cylinder pressure, fuel line pressure and crank angle were acquired using a National Instruments PCIO-MX16-E PC-BNC rack interface coupled with a BNC 2090 capture board. Cylinder pressure was measured using a Kistler type 6053B60 piezocapacitive transducer connected to a Type 5011 charge amplifier. Fuel line pressure was obtained using a Kistler 4065A piezoresistive sensor and 4617A amplifier. This data was recorded at a resolution of 0.5 degrees crank angle on the falling edge of the 
crank degree marker (CDM) signal from an AVL optical encoder, mounted directly on the engine crankshaft. The encoder also supplied a single pulse per revolution signal to mark TDC and trigger data acquisition of 50 consecutive four stroke cycles. Emissions measurements were obtained using an AVL 415 Variable Sampling Smoke Meter for smoke opacity and a Horiba MEXA-7100 HEGR exhaust gas analyzer system for NOx using a chemiluminescent method.

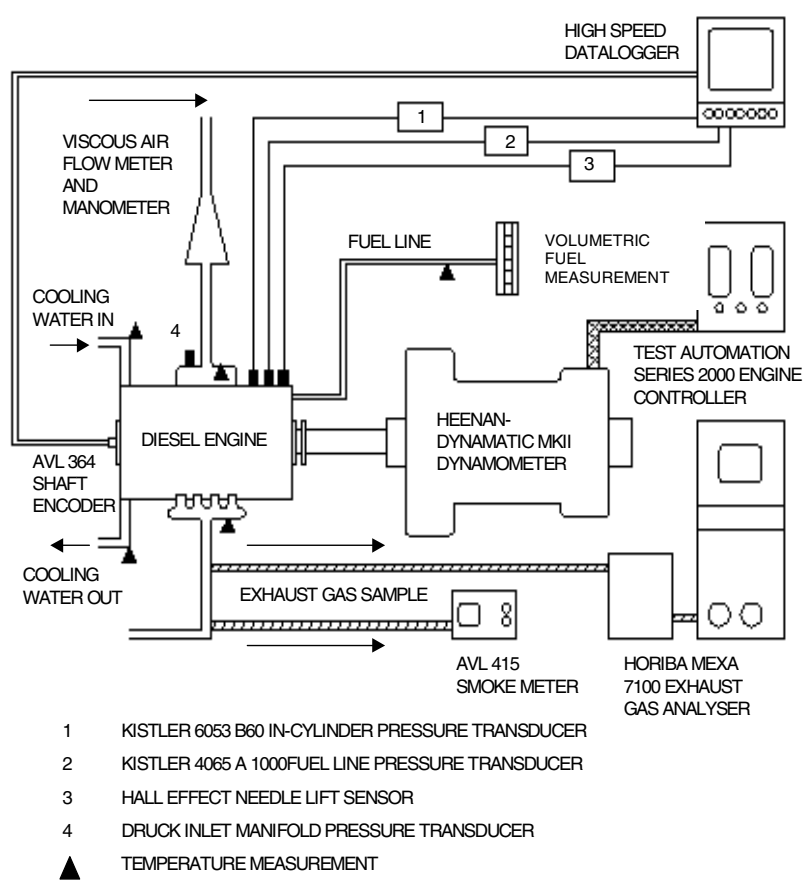

Figure 1 - Schematic diagram of the test engine and equipment

During this study, engine performance and emissions data were obtained under steady state operating conditions at five loads corresponding to $0 \%, 25 \%, 50 \%$, $75 \%$ and $100 \%$ load, and at two speeds of $1500 \mathrm{rpm}$ (synchronous speed) and $2000 \mathrm{rpm}$ (maximum torque speed). To ensure repeatability and consistent operating conditions, the engine was first run for approximately 10 minutes at $1500 \mathrm{rpm}$ at $50 \%$ load until the cooling water temperature leaving the cylinder head reached $80{ }^{\circ} \mathrm{C}$, and the exhaust gas temperature reached $250{ }^{\circ} \mathrm{C}$. Once these conditions had been achieved, the engine was brought to the required test point, and allowed to settle there for at least 1 minute before collection of data began.

The first and last sets of data to be acquired were for standard diesel No 2, and the full fuel specifications are given in table A1. The first data set served as a baseline to which the results of the different biodiesel fuels could be compared, and the last data set ensured that the results were repeatable, and proved that the engine performance had not been impaired by the use of biodiesel fuels.

\section{RESULTS AND DISCUSSION}

\section{FUEL PROPERTIES}

Table 2 shows LCV and density for the fuels used in the study. Mineral diesel has higher LCV than the other three fuels.

\begin{tabular}{|l|l|l|l|l|}
\hline PROPERTY & DIESEL & RAPE & SOY & $\begin{array}{l}\text { WASTE } \\
\text { Oil }\end{array}$ \\
\hline LCV (kJ/Kg) & 42026 & 39826 & 39622 & 39651 \\
\hline LCV $\left(\mathbf{m J} / \mathbf{m}^{3}\right)$ & 35562.4 & 35046.8 & 35065.4 & 34773.9 \\
\hline $\begin{array}{l}\text { Density at } \\
\mathbf{1 5} \mathbf{5}^{\circ} \mathbf{C}\left(\mathbf{k g} / \mathbf{m}^{\mathbf{3}}\right)\end{array}$ & 846.2 & 880 & 885 & 877 \\
\hline
\end{tabular}

Table 2 LCV and density of the pure biodiesel fuels

In table 3 values for Cetane number (CN) are shown for the fuels and their various blends. This data was calculated using the work of Van Gerpen [7]. Table 3 also contains values of viscosities. The lowest value is displayed by mineral diesel and the highest by the fuel produced from waste cooking oil.

\begin{tabular}{|c|c|c|c|}
\hline \multicolumn{4}{|c|}{ Cetane Number } \\
\hline Fuel & Rape & Soy & Waste Oil \\
\hline $5 \%$ & 47.6 & 47.4 & 47.4 \\
\hline $50 \%$ & 50.6 & 51.4 & 51.2 \\
\hline $100 \%$ & 53.9 & 59 & 63.2 \\
\hline Diesel & \multicolumn{3}{|c|}{54} \\
\hline \multicolumn{4}{|c|}{ Kinematic Viscosity $\left(\mathrm{mm}^{2} / \mathrm{s}\right)$} \\
\hline $5 \%$ & 2.482 & 2.461 & 3.444 \\
\hline $50 \%$ & 3.189 & 3.308 & 4.459 \\
\hline $100 \%$ & 4.546 & 4.63 & 5.85 \\
\hline Diesel & \multicolumn{3}{|c|}{2.453} \\
\hline
\end{tabular}

Table 3 Cetane number of each of the fuels and their blends [8], and kinematic viscosity of biodiesel and blends at $40^{\circ} \mathrm{C}$

\section{ENGINE POWER}

In order to asses any degradation in engine performance, the maximum power output of each biodiesel blend was recorded at two different speeds. The results are expressed as a percentage of the maximum power output obtained when the engine was operated at the same conditions using mineral diesel in table 5.

The error in these results arising from fluctuations in speed and torque was calculated as $1 \%$. It can therefore be seen that a five percent blend of any of the three biodiesel fuels causes negligible decrease in maximum power output of the engine at both speeds, for rape and soy. 


\begin{tabular}{|l|l|l|l|l|l|l|}
\hline Fuel & Rape & Soy & Waste & Rape & Soy & Waste \\
\hline Blend & \multicolumn{3}{|c}{$1500 \mathrm{rpm}$} & \multicolumn{3}{|c|}{ 2000rpm } \\
\hline $\mathbf{5 \%}$ & 98.20 & 99.33 & 98.15 & 100.35 & 98.98 & 97.43 \\
\hline $\mathbf{5 0} \%$ & 99.74 & 99.24 & 98.47 & 98.66 & 95.33 & 96.62 \\
\hline $\mathbf{1 0 0} \%$ & 95.67 & 92.11 & 94.53 & 89.82 & 91.30 & 95.14 \\
\hline
\end{tabular}

Table 5 - Maximum power produced at 1500 and 2000 rpm of the various fuels expressed as a percentage of power produced by mineral diesel $(100 \%$ at each point)

At $1500 \mathrm{rpm}, \mathrm{R} 50, \mathrm{~S} 50$ and W50 have negligible decrease in power, but as the speed is increased to $2000 \mathrm{rpm}$, a decrease in power of up to $5 \%$ is recorded. The reduction in maximum power output becomes more significant when the engine is fuelled with the pure biodiesel fuels, and is especially emphasized at higher speeds. At $2000 \mathrm{rpm}$, a ten percent reduction in maximum power was observed with the rape and soy derivative fuels. The differences between rape and soy were small, but it would appear that the rape derivative fuel produced on average a higher maximum power output than soy.

These results are in keeping with the data of table 2 where the LCV for mineral diesel was greater than those for all three biodiesel fuels. The three biodiesel fuels have lower energy content on a volumetric basis, and without any changes in the fuel equipment (i.e. given the same volume of fuel injected), it can be therefore expected that the power output of the engine will be reduced with biodiesel. On a volumetric basis, Rape has the highest energy content of the three biodiesel fuels, which would suggest that when the engine is fueled by the rape biodiesel it should show the smallest reduction in power output. Whilst this is true for the biodiesel blends, it is not the case for the pure methyl esters.

The results for the pure biodiesel fuels are better interpreted in terms of their CN (Table 3). W100 has the highest $\mathrm{CN}$ and the highest power output. This might also explain the results at the higher speed in Table 6 where R100 shows the lowest power and also the lowest $\mathrm{CN}$. This would suggest that for unblended oils $\mathrm{CN}$ is a better indicator of performance than LCV.

Other fuel quality issues causing degradation of power could be caused by fuel filter plugging, gum like deposits on injection equipment and injector cavitations, although due to the relatively short term duration of the engine tests, these effects would be small, if present.

\section{SPECIFIC ENERGY CONSUMPTION}

The specific energy consumption (SEC) of the engine operating on the different fuels is plotted in figure 2 for $1500 \mathrm{rpm}$. The data shows that there is little variation for $5 \%$ blends, and the $50 \%$ blends tend to show slightly higher sec than for mineral diesel. As expected, the biodiesel trends follow mineral diesel (in that SEC is reduced as load is increased); and the values tend to converge to similar values near $100 \%$ load.

It is unsurprising that SEC is higher for the biodiesel fuels, given their lower LCV. At low loads, the operating temperature is lower, which results in poor spray characteristics as the biodiesel fuels have higher viscosity. The net effect is that more fuel is required to produce the same power output.

Overall, pure rape biodiesel exhibited the best SEC, whilst waste and soy biodiesels exhibited similar, slightly lower values due to their lower LCV. The trends were identical for $2000 \mathrm{rpm}$, although slightly less pronounced.

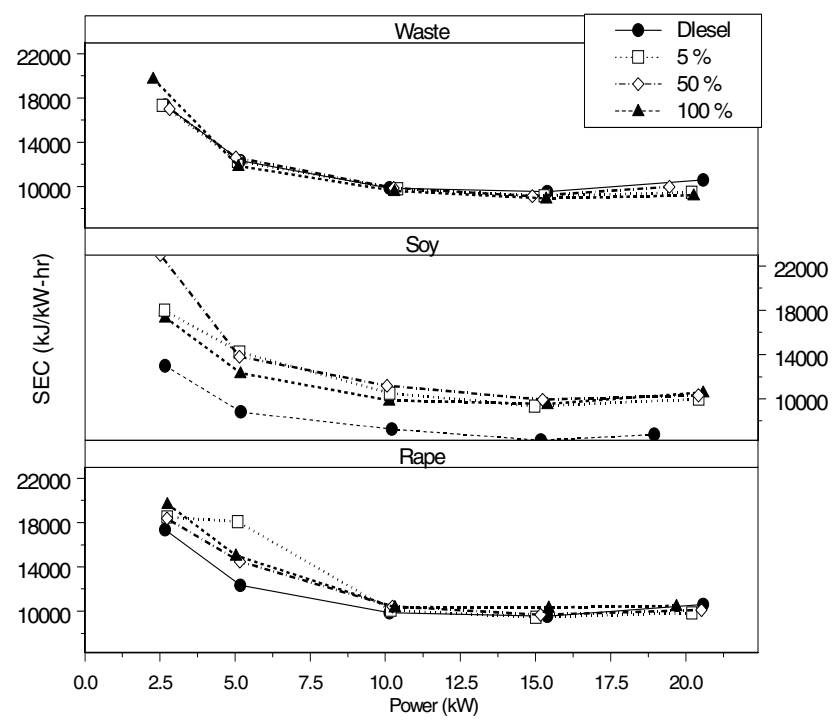

Figure 2 - SEC plotted against power for all fuels at 1500 rpm

\section{BSNOX EMISSIONS}

The Brake specific NOx readings are presented at the maximum torque condition of $2000 \mathrm{rpm}$ in figure 3 , (the results at $1500 \mathrm{rpm}$ showed the same trends). The difference in emissions of BsNOx for all $5 \%$ blends compared with diesel are so small as to be negligible. For rape and soy the BsNOx values converge to be approximately the same at above $50 \%$ load (12kW), whilst for waste oil the convergence occurs at $100 \%$ load. The most marked differences are observed at low loads where significant reductions in $\mathrm{BsNOx}$ are observed with biodiesel. For R100 and S100, BsNOx was reduced to approximately half of the diesel value. The waste oil results showed a different trend where BsNOx emissions were lower with W50 than W100. Overall, BsNOx emissions were the lowest for soy biodiesel, which also has the lowest fuel borne oxygen content (table A3).

It has been previously reported [2, 9], that NOx emissions are strongly related to cylinder pressure development, (and confirmed here). Higher combustion 
temperatures and earlier heat release rates caused by the greater fuel borne oxygen content would tend to increase BsNOx. This effect has not occurred in these tests as the fuel system was not optimized for biodiesel operation (injection timing and injected fuel quantity were held constant). It is interesting to note that Salvatore and Maddaleena [10] found that NOx in a biodiesel fuelled engine can be significantly reduced by an EGR system that includes an oxidizing catalyst.

A second reason for the lower BsNOx recorded in this study is thought to be due to the higher viscosity of the fuels leading to poor spray characteristics that reduced combustion efficiency and hence maximum combustion temperature [11].

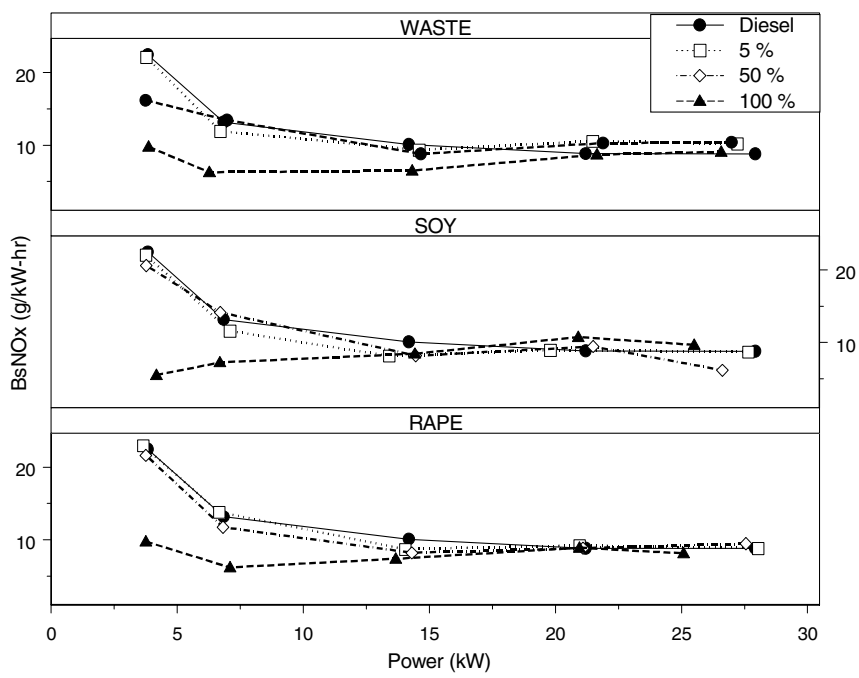

Figure 3 - NOx plotted against power for the all fuels, at $2000 \mathrm{rpm}$. Diesel results are plotted in each pane.

The convergence of BsNOx emissions levels beyond $50 \%$ load is probably due to the increased in cylinder operating temperatures that reduce the effect of the increased viscosity of the biodiesel fuels compared with No 2 diesel. This is confirmed to some extent by Ramadhas et al. [11] who reported that density and viscosity effects are particularly important at low loads. Higher viscosity in biodiesel fuels is known to result in poorer atomization, reduced spray penetration, decreased cone angle [12], and a greater droplet size, resulting in a lower amount of air entrainment leading to poorer combustion efficiency and hence lower combustion temperatures which is confirmed by the extended ignition delays in figure 5). The higher temperatures beyond $50 \%$ load may have mitigated the deterioration in injector performance, and the increased kinetic energy of the fuel resulted in more energy for atomization.

\section{SMOKE EMISSIONS}

At low load (up to approximately $5 \mathrm{~kW}$ ) there is negligible difference between the smoke emissions of any biodiesel as compared to mineral diesel. Beyond $25 \%$ load, the emissions of smoke are always lower than for corresponding mineral diesel operation, except for the $5 \%$ blends where there is negligible difference, as shown in figure 4.

As the proportion of biodiesel is increased in the blend, the emissions of visible smoke decrease, except for the waste oil where the results from $50 \%$ blend and pure waste oil were virtually the same. Overall, the lowest smoke emissions were always recorded with rape blends.

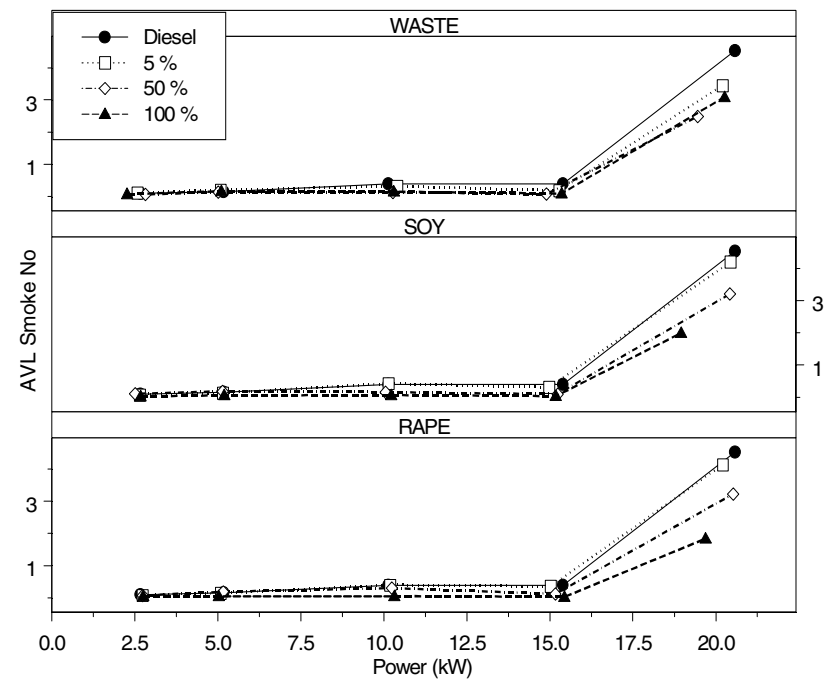

Figure 4 - AVL Smoke Number plotted against power for the all fuels, at $1500 \mathrm{rpm}$. Diesel results are plotted in each pane

The smoke results at $2000 \mathrm{rpm}$ followed the same trends, except that at the higher speed the reductions in smoke are less distinct. R100 produced the lowest smoke levels of all the biodiesel fuels, and at low load the visible smoke levels were so low that they were at the limit of what could be measured with the laboratory equipment.

Overall, W100 and W50 produced higher levels of smoke compared with the corresponding rape and soy fuels, possibly due to increased number of carbon atoms in the fuel and hence a greater degree of pyrolysis. According to Ramadhas et al. [11], biodiesel's smoke reducing effect could be attributed to its displacement of aromatic and short chain paraffin hydrocarbons and its higher oxygen content compared with No 2 diesel. But Ramadhas et al. [11] also observed that smoke emissions increase at cold start.

It was noted that at $100 \%$ load injection pressure decreased with the biodiesel fuels, which was particularly evident for the $50 \%$ blends. This might be due to poor mixing of the blends, by the method adopted here and referred to as 'splash mixing'. A more prolonged and intense mixing regime may have been required. The observations relating to injection pressure would have been a greater factor at high loads, where the higher 
injection pressures would have caused the cone angle of the spray to increase [12], (whereas at low loads, the cone angle was decreased). This increasing cone angle would have increased air entrainment and the higher oxygen levels result in less smoke, but this is unlikely to be the dominant effect in light of reduced NOx emissions.

The presence in biodiesel fuels of oxygenated compounds (table A3) may provide a route for the generation of $\mathrm{OH}$ radicals that are thought to be active in the removal of smoke [12] and [3].

\section{IGNITION DELAY}

Differences in the combustion process (and hence performance and emissions trends) can be particularly attributed to differences in ignition delay so it is worth considering this effect in some detail. The ignition delay was calculated as the crank angle interval between start of injection and start of combustion, (found from experimental data). Start of injection was defined as the crank angle where fuel line pressure first exceeded the nozzle opening pressure of 235 bar, and start of combustion was found from the heat release rate analysis where the net heat release rate first reaches zero after a small dip coinciding with fuel injection [13]. Start of combustion was then confirmed by checking that the second derivative of cylinder pressure with respect to volume was zero.

Choi [3] reported that emissions, particularly of NOx and smoke are sensitive to SOI timings, especially at low load, and so for this reason the injection timing was not deliberately changed when different biodiesel fuels were tested. This engine was run under one set of operating conditions to allow for direct comparison between fuels. However, it was noted that at low loads, where the viscosity effect of biodiesel are most important that the SOI did change at both engine speeds, with SOI occurring later as the biodiesel concentration was increased (as it took longer for the fuel line pressure to exceed nozzle opening pressure). This effect was more pronounced with soy and waste than rape, which follows from bulk modulus and viscosity data, but not from the density measurements. According to the density differences, the waste oil SOI should have occurred first. This suggests that the bulk modulus and viscosity effects are more important than the density differences.

Ignition delay decreased as load increased for all fuels as expected (figure five), and converged to the same shorter values as for diesel beyond $75 \%$ load. Once again, the results for the $5 \%$ blends were almost identical to diesel values, and so have been omitted from the graph. It can be seen that for $50 \%$ and $100 \%$ blends, ignition delays were increased at low loads; with the longest ignition delays being observed with S100, and the shortest with rape biodiesel

The results for ignition delay in figure 5 are presented for $1500 \mathrm{rpm}$. Ignition delay increased with the addition of biodiesel. It is also particularly interesting to note that there was some evidence of a two stage ignition process where the $50 \%$ blends do not always lie equally between mineral diesel and pure biodiesel. This is particularly striking for R50 where the ignition delay value is much closer to diesel values, supporting the argument that the diesel in the blend ignites earlier. This is discussed more fully in the following section.

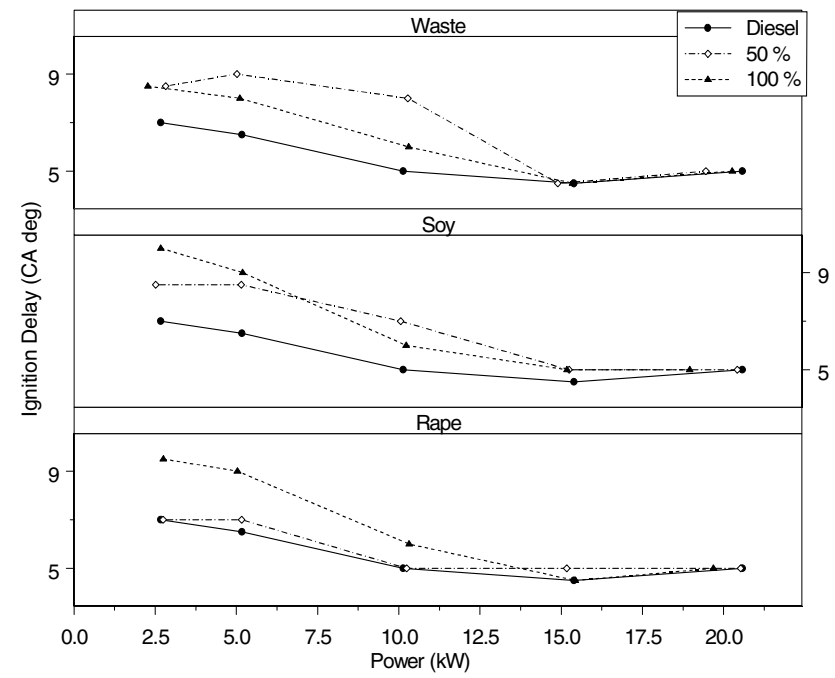

Figure 5 - Ignition Delay at 1500 rpm

\section{RATE OF HEAT RELEASED}

High speed cylinder pressure data were recorded over 50 consecutive engine cycles and then averaged. A simple single zone heat release analysis based on the method presented by Heywood [14] was performed here on each set of data. The results presented here are confined to $50 \%$ and $100 \%$ biodiesel blends due to the negligible differences observed with $5 \%$ blends as compared to mineral diesel. The results at $25 \%$ load for rape are presented in figure six. As load was increased, the values of heat release rate (and cylinder pressure development) converged to similar values as mineral diesel, so the low load cases showing more marked differences are presented, and discussed in more detail here.

For the rape derivative fuels, the heat release rate is markedly reduced and delayed compared to diesel operation, but the heat release of R50 is almost identical to that for mineral diesel. It is proposed that the reason for this is that for R50, the diesel component acted as a catalyst that promoted the biodiesel combustion process [15]. The lower NOx levels for R100 can be explained by the lower initial temperatures, and the low smoke can be explained by the longer diffusion burning period, and extended combustion duration. 


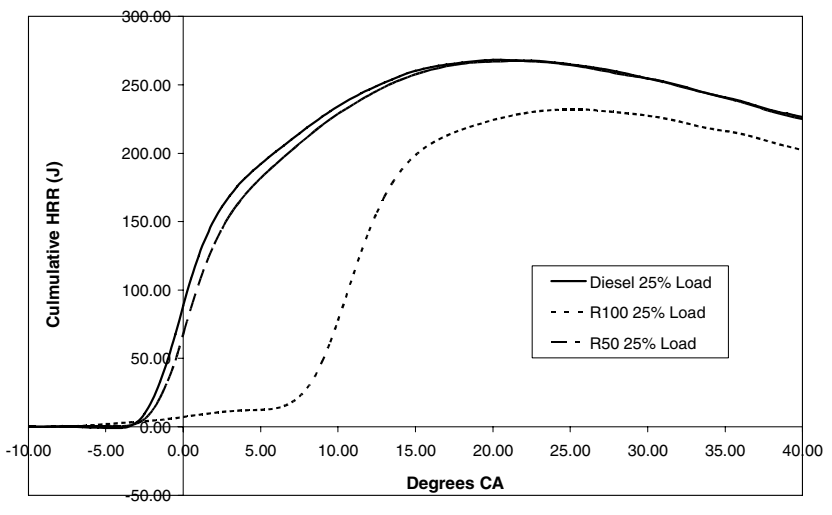

Figure 6-Cumulative heat release comparison of rape at $25 \%$ load and $1500 \mathrm{rpm}$

The fuel line injection pressures at $25 \%$ load for rape are shown in figure 7, where it can be seen that start of injection is delayed only slightly for R50 (by 2.5 CAD). The start of injection is delayed to a much greater extent for R100. It is not surprising that the effect correlates well with the delayed SOC. But given that the observed increase in ignition delay is only $0.5 \mathrm{CAD}$ later than for diesel, the late injection cannot fully explain the very close heat release rates of mineral diesel and R50 unless the proposed ignition mechanism is valid.

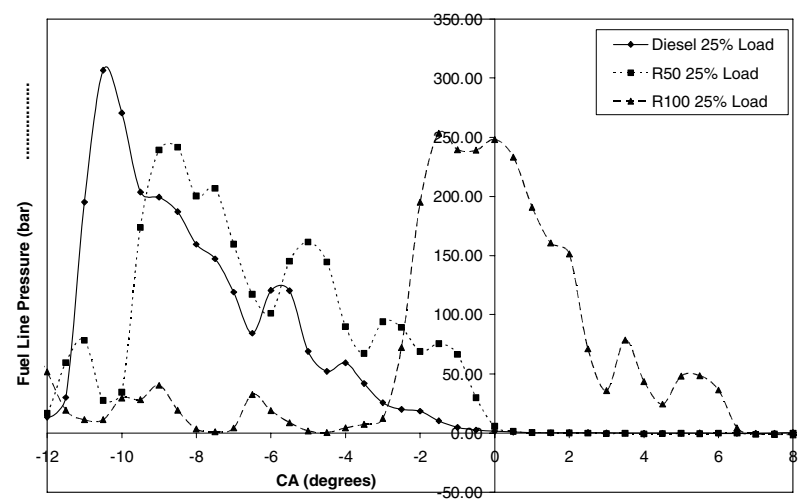

Figure 7 - Fuel line pressure comparison of rape at $25 \%$ load and $1500 \mathrm{rpm}$

A similar comparison for soy biodiesel is presented in figure 8. In this case, the results for S50 lie between S100 and diesel, unlike for rape. The SOC occurs much earlier for S100 than R100, and the late combustion heat release rates are higher with soy biodiesel than for mineral diesel and for rape. The soy blends showed the least reduction in peak cylinder pressure, but the position of peak cylinder pressure was delayed compared with rape due to longer injection durations caused by higher viscosity. When combined with the increased ignition delay, this leads to delayed combustion, and thus lower NOx. The higher late combustion rates are most likely to be due to increased oxygen content of the fuel, and a limited premixed combustion phase that led to increased diffusion burning.

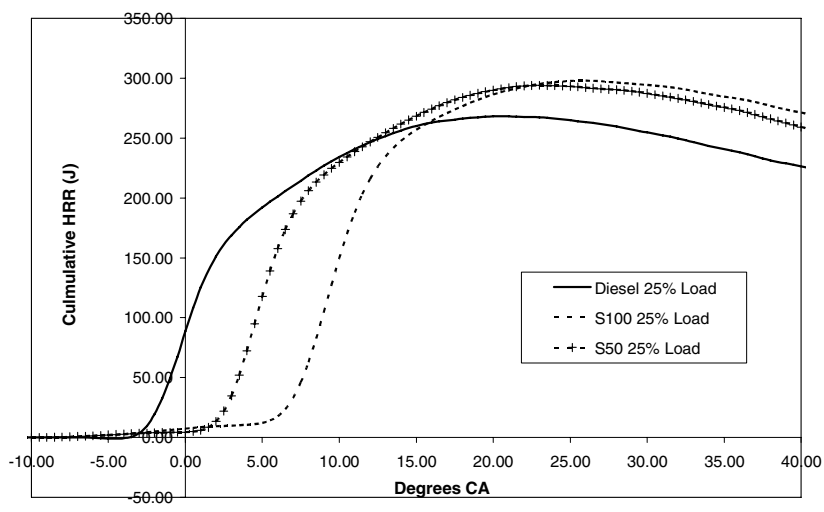

Figure 8 - Cumulative heat release comparison of soy at $25 \%$ load and $1500 \mathrm{rpm}$

The fuel line pressures for soy at $25 \%$ load are shown in figure 9 , where it can be seen that at the percentage of biodiesel increases in the blend, the start of injection is delayed by almost the same proportion. Thus a simple explanation of the delayed combustion is found. However, delayed start of combustion should not lead to ultimately higher rates of heat release that are demonstrated with the soy blends compared with diesel. If the late injection was the only explanation, the trends should follow those of R100 shown in figure 6 .

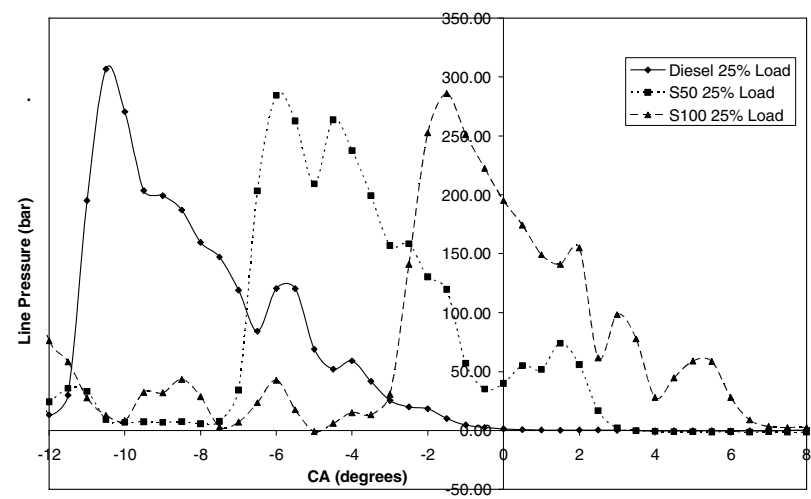

Figure 9 - Fuel line pressure comparison of soy at $25 \%$ load and $1500 \mathrm{rpm}$

The results for waste biodiesel, presented in figure 10 show another, different trend. This time, the heat release of W50 was more delayed than W100. Peak cylinder pressures were lower for waste oil than for the other biodiesel fuels, and position of peak cylinder pressure was delayed by the greatest extent. It is also interesting to note that the coefficient of variance between peak cylinder pressures on a cycle to cycle basis was greater for waste than for any of the other biodiesels (and lowest for rape).

Waste oil trends have in many cases behaved slightly differently to rape and soy, whilst they have followed the same pattern in others. This erratic behavior is best demonstrated by the heat release rate analysis. Waste 
oil properties and behavior can be attributed to high level of free fatty acid in the initial oil mixture (a result of the high temperatures that the oil was subjected to during its life time, table A5), which leads to formation of soaps in the biodiesel; and this in tern lead to the degradation of the fatty acid methyl ester (biodiesel)[16]. It was not possible in the present research to asses the extent to which mixing as discussed above may have lead to inhomogeneous mixtures.

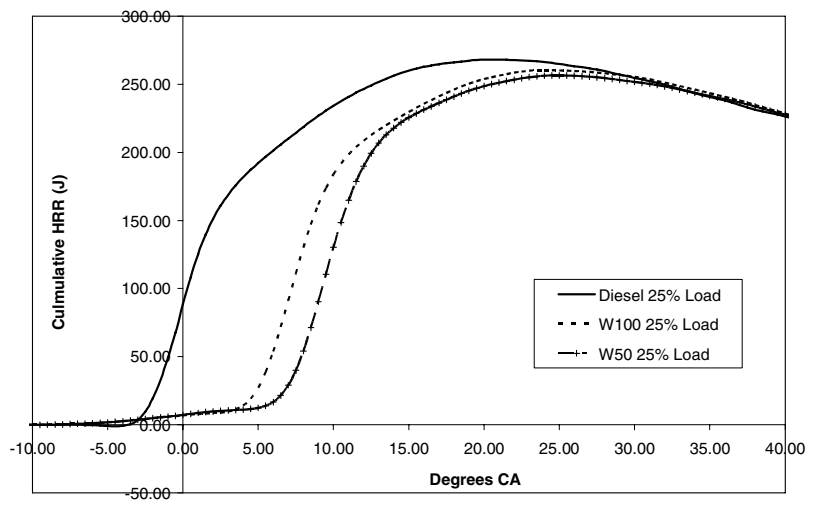

Figure 10 - Heat release rate comparison of waste oil at $25 \%$ load and $1500 \mathrm{rpm}$

The fuel line pressure data for waste oil at $25 \%$ load are shown in figure 11. It can be seen that there is some correlation with the heat release data as the start of injection is more delayed for W50 than W100. On the basis of viscosity or density data of the blends there is no explanation for this trend. Thus whether the delayed injection is a chemical issue, or indicates that waste oil yielded the most inconsistent blend with mineral diesel, or that waste oil was the fuel most likely to degrade remains the subject for further research.

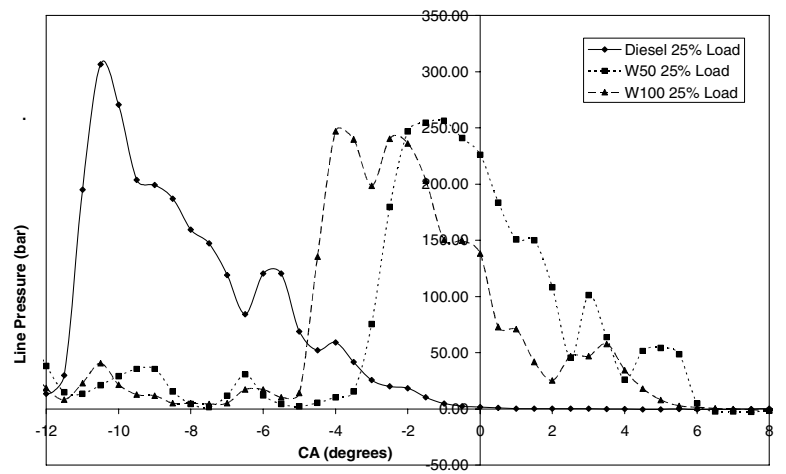

Figure 11 - Fuel line pressure comparison of waste at $25 \%$ load and $1500 \mathrm{rpm}$

For comparison, results for rape at $100 \%$ load are presented in figure 11. These are typical of all the results at higher loads, where the biodiesel heat release characteristics are much closer to diesel for all fuels. It is evident again that the R50 trend lies much closer to diesel than R100, and all trends observed in the preceding discussion are repeated at higher loads, and the higher speed. It is worth noting that for all the biodiesel fuels and their blends, the cyclic variability in the data was increased compared with mineral diesel.

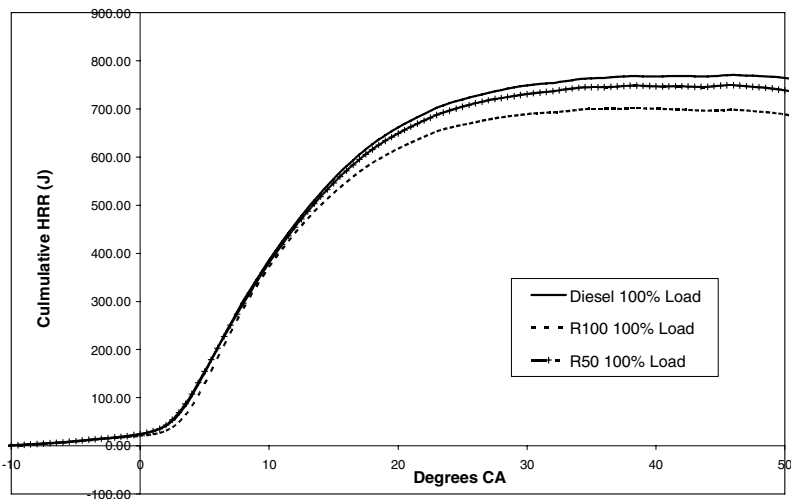

Figure 11 - Heat release rate comparison of R50 and $\mathrm{R} 100$ at $100 \%$ load and $2000 \mathrm{rpm}$

\section{CONCLUSION}

Biodiesel produced from different source oils leads to different performance characteristics, as a result of different chemical compositions of the methyl ester, and slightly different physical properties.

Of all the different physical properties of biodiesel compared with mineral diesel, it was found that the closest correlations to performance are given by the LCV of the biodiesel fuels when they are blended with mineral diesel. There is some correlation between viscosity and engine performance at low load, but density changes have little effect. $\mathrm{CN}$ was found to be a better predictor of engine performance for the pure biodiesels.

A blend of $5 \%$ by volume of a biodiesel fuel in mineral diesel does not affect any of the measured performance or emissions characteristics. This would imply that the addition of small quantities of biodiesel to mineral diesel is a suitable strategy for increasing alternative fuel consumption, at least in agricultural engines, or as an introduction to diesel consumers in countries where biodiesel utilization in not yet established such as the UK

If an unmodified industrial engine is to be fuelled with biodiesel in 50:50 mixtures, or as a pure biodiesel, a reduction in NOx at low loads and a reduction in smoke at high loads can be expected. The penalty of this is increased sec, and a reduction in power output.

The initial findings presented in this paper suggest that for 50:50 mixtures of biodiesel and mineral diesel, there is evidence of a two stage ignition process, with the diesel fuel igniting first, and hence controlling the combustion pattern of biodiesel. Whether this is only a result of blending procedure remains a subject for further research. 
Ignition delay is longer with biodiesel than for mineral diesel, and shows complicated trends where biodiesel is blended with mineral diesel. This leads to delayed combustion and lower peak cylinder pressures than for mineral diesel, which contradicts the effects of the higher $\mathrm{CN}$ of the biodiesel fuels.

NOx emissions were reduced at low load with negligible effect on soot; at high load soot emissions were reduced with negligible effect on NOx. Thus the use of biodiesel fuels would appear to present a beneficial means of manipulating the traditional NOx/smoke trade-off.

Overall, in an unmodified engine, rape derivative fuel gave the best combustion and emissions performance.

\section{REFERENCES}

1. Arida, V.P., A. Atienza, F.C. Borlaza, and D.L. Binlayo, Pilot Plant Production and Development of a Diesel Fuel Substitute from Coconut Oil, Alternative Energy Sources. V Part D:(1983).

2. Babu, A.K. and G. Devaradjane, Vegetable Oils And Their Derivatives As Fuels For Cl Engines: An Overview, SAE Paper, 2003-01-0767:(2003).

3. Choi, C.Y., G.R. Bower, and R.D. Reitz, Effects of Biodiesel Blended Fuels and Multiple Injections on DI Diesel Engines, SAE Paper, 970218:(1997).

4. Goering, C.E., M.J. Schwab, E.H. Daugherty, E.H. Pryde, and A.J. Heakin. Fuel properties of eleven vegetable oils. in ASAE. 1982. St Joseph, MI: ASAE. 5. Harvey, A. and B. Skelton, What is in your tank?, TCE, may 2004:(2004).

6. Zhou, P.L., A.M. Fet, O. Michelsen, and K. Fet, $A$ feasibility study of using biodiesel in recreational boats in the UK, Journal of Engineering for the Maritime:(2002).

7. Van Gerpen, J. Cetane Number Testing of Biodiesel. in Proceedings of the Third Liquid Fuel Conference. 1996. Nashville, TN: American Society of Agricultural Engineers.

8. Addy, J.M., A. Bining, P. Norton, E. Peterson, K. Campbell, and O. Bevillaqua, Demonstration of Caterpillar C10 Dual Fuel Natural Gas Engines in Commuter Buses, SAE Paper, 2000-01-1386:(2000). 9. Usta, N., E. Ozturk, O. Can, E.S. Conkur, S. Nas, A.H. Con, A.C. Can, and M. Topcu, Combustion of biodiesel fuel produced from hazelnut soapstock/waste sunflower oil mixture in a Diesel engine, Energy Conservation and Management:(2004).

10. Salvatore, A. and A. Maddaleena, The effect of methyl ester of rapeseed oil on combustion and emissions of D.I diesel engines, SAE Paper, 932801:(1993).

11. Ramadhas, A.S., S. Jayaraj, and C. Muraleedharan, Use of vegetable oils as I.C. engine fuels - A review, Renewable Energy. 29:(2004).

12. Varde, K.S., Some Correlation of Diesel Engine Performance with Injection Characteristics Using Vegetable Oil as Fuel. (1982), American Society of Agricultural Engineers: St Joseph, MI. p. 303-311. 13. Stone, R., Introduction to Internal Combustion Engines, Macmillan Press Ltd. (1999)
14. Heywood, J.B., Internal Combustion Engine Fundamentals, McGraw-Hill. (1988).

15. Milovanovic, N., R. Chen, R. Dowden, and Turner. J, An investigation of using various diesel-type fuels in homogenous charge compression ignition engines and their effects on operational and controlling issues, International Journal of Engine Research. 54:(2004).

16. McDonnell, K., S. Ward, J.J. Leahy, and P. McNulty, Properties of Rapeseed Oil for Use as a Diesel Fuel Extender, JAOCS. 76:(1999).

\section{APPENDIX}

\section{FURTHER TECHNICAL DATA OF THE FUELS}

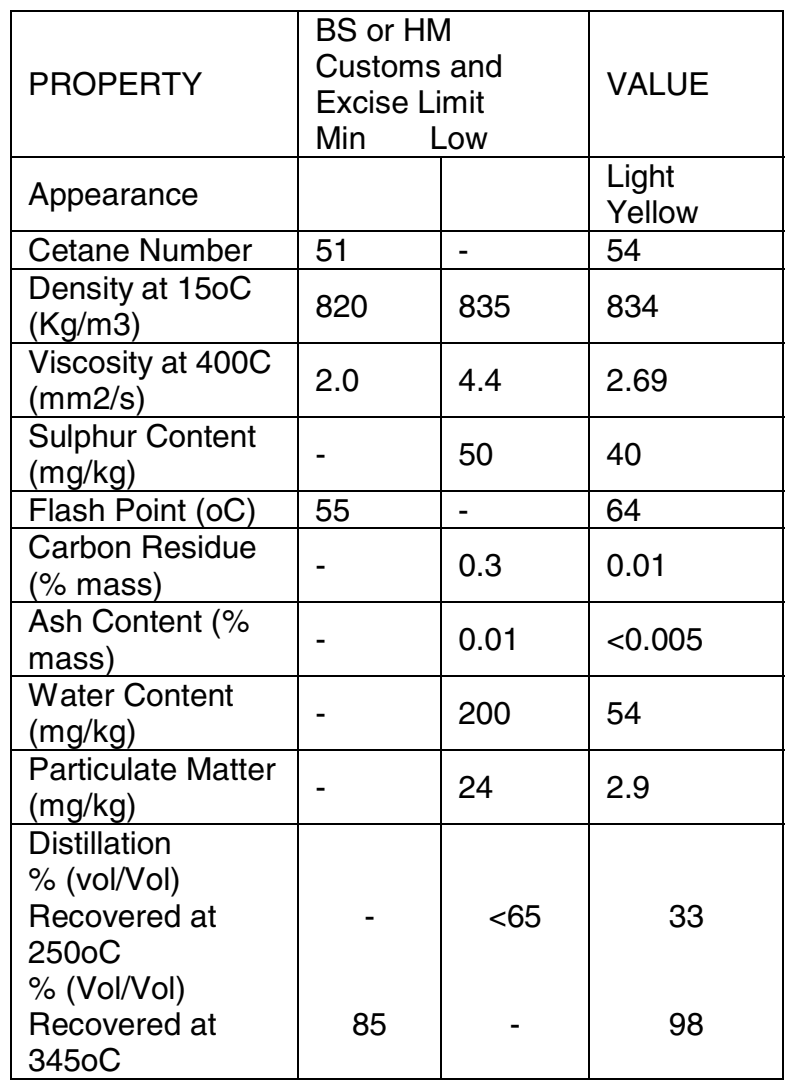

Table A1 Properties of ESSO Ultra Low Sulphur Diesel from Esso Marketing

\begin{tabular}{|c|c|c|c|}
\hline \multicolumn{4}{|c|}{ Biodiesel Pour Point Test Results (degrees C) } \\
\hline Fuel & Rape & Soy & Waste Oil \\
\hline $\mathbf{5 \%}$ & -21 & -21 & -18 \\
\hline $\mathbf{5 0} \%$ & -9 & -15 & 3 \\
\hline $\mathbf{1 0 0} \%$ & -1 & -4 & 11 \\
\hline Diesel & \multicolumn{4}{|c|}{-27} \\
\hline Biodiesel Cloud Point Test Results (degrees C) \\
\hline $\mathbf{5 \%}$ & -16 & -17 & -15 \\
\hline $\mathbf{5 0} \%$ & -9 & -10 & -2 \\
\hline $\mathbf{1 0 0} \%$ & 2 & -3 & 14 \\
\hline Diesel & \multicolumn{4}{|c}{} \\
\hline
\end{tabular}

Table A2 Blend pour point and cloud point test results 


\begin{tabular}{|l|c|c|c|}
\cline { 2 - 4 } \multicolumn{1}{c|}{} & \multicolumn{3}{c|}{ Composition by wt\% } \\
\hline Rape & C & H & O \\
\hline Soy & 76.88 & 11.67 & 11.4 \\
\hline Waste Oil & 76.84 & 12.03 & 10.79 \\
\hline
\end{tabular}

Table A3 Elemental composition of the fuels by GC/MS analysis

\begin{tabular}{|c|c|c|c|}
\cline { 2 - 4 } \multicolumn{1}{c|}{} & Rape & Soy & $\begin{array}{c}\text { Waste } \\
\text { Oil }\end{array}$ \\
\hline $\begin{array}{c}\text { Methyl } \\
\text { Laurate }\end{array}$ & (trace) & (trace) & 0.12 \\
\hline $\begin{array}{c}\text { Methyl } \\
\text { Myristate }\end{array}$ & 0.09 & 0.07 & 1.86 \\
\hline $\begin{array}{c}\text { Methyl } \\
\text { Palmitate }\end{array}$ & 10.54 & 5.25 & 24.49 \\
\hline $\begin{array}{c}\text { Methyl } \\
\text { Stearate }\end{array}$ & 3.75 & 2.46 & 14.39 \\
\hline $\begin{array}{c}\text { Methyl } \\
\text { Oleate }\end{array}$ & 23.18 & 58.09 & 38.32 \\
\hline $\begin{array}{c}\text { Methyl } \\
\text { Linoleate }\end{array}$ & 48.92 & 21.79 & 13.44 \\
\hline $\begin{array}{c}\text { Methyl } \\
\text { Linoleneate }\end{array}$ & 1.16 & 0.41 & 0.33 \\
\hline $\begin{array}{c}\text { Others at } \\
\text { low traces }\end{array}$ & 12.23 & 11.71 & 4.37 \\
\hline Table A4 GC/MS analysis of the three biodieselfues.
\end{tabular}

Table A4 GC/MS analysis of the three biodiesel fuels. Chemical composition were found using the GC/MS (HP 5890 GC coupled with a Trio 1000 MS with a Supilco DB5 Carbowax capillary collom $30 \mathrm{~m}$ long and $0.25 \mathrm{~mm}$ diameter).

\begin{tabular}{|c|c|c|c|}
\hline \multicolumn{4}{|c|}{ Glyceride Content } \\
\hline Fuel & Rape & Soy & Waste Oil \\
\hline Free Glycerin & 0.001 & 0.001 & 0.0 \\
\hline Mono & 0.87 & 0.783 & 0.563 \\
\hline Di & 1.358 & 0.02 & 0.093 \\
\hline Tri & 3.542 & 0.01 & 0.005 \\
\hline
\end{tabular}

Table A5 Glyceride content of each fuel by Christina Planc method using a GC/FID (Elmer Perkins). 